\title{
Coinfections in Injection Drug Users Should be Interpreted Carefully
}

\author{
Seyed Moayed Alavian, ${ }^{1, *}$ \\ ${ }^{1}$ Department of Gastroenterology and Hepatology, Director of Baqiyatallah Research Center for Gastroenterology and Liver Disease, Tehran, IR Iran \\ "Corresponding author: Seyed Moayed Alavian, Department of Gastroenterology and Hepatology, Director of Baqiyatallah Research Center for Gastroenterology and Liver \\ Disease, P.O. Box 14155/3651, Tehran, IR Iran. Tel/Fax: +98-2188945186-8; +98-2181262072, E-mail: alavian@thc.ir
}

Received 2016 May 13; Revised 2016 September 13; Accepted 2016 November 29.

I read with interest the recently published article by Norouzian et al.(1). The epidemiology of hepatitis B virus (HBV)and hepatitis $\mathrm{C}$ virus (HCV) infections has changed during the recent years and their endemicity is low $(2,3)$, but the prevalence of such infections in inmates with high-risk behaviors is still high (4). Norouzian et al. perfectly showed the main risk factors for such infections. The harm reduction program is an advanced one in Iran, which results in lower rates of such infections in the injection drug users (IDUs). HIV and HCV coinfection is directly related to the route of HIV transmission in the communities such as Turkey, which the most cases are related to sexual contact and the coinfection with HCV infection is low (5); while, in Iranian community it is related to intravenous drug abuse. Finally, I would like to mention that antiHCV antibody-positive is not parallel to HCV infection and may be reported in some patients with the history of anti-HCV therapy or the ones who lost the infection. I suggest HCV RNA testing in the ones with anti-HCV antibody-positive response.

\section{References}

1. Norouzian H, Gholami M, Shakib P, Goudarzi G, Diali HG, Rezvani A. Prevalence of HCV Infections and Co-Infection With HBV and HIV and Associated Risk Factors Among Addicts in Drug Treatment Centers, Lorestan Province, Iran. Int J High Risk Behav Addict. 2016;5(1).

2. Fattahi MR, Safarpour A, Sepehrimanesh M, Hosseini Asl SM, Mohamaddoust F. The prevalence of hepatitis C virus infection and its related risk factors among the rural population of fars province, southern iran. Hepat Mon. 2015;15(2):e24734. doi: 10.5812/hepatmon.24734. [PubMed: 25788957].

3. Keyvani H, Sohrabi M, Zamani F, Poustchi H, Ashrafi H, Saeedian F, et al. A population based study on hepatitis B virus in northern iran, amol. Hepat Mon. 2014;14(8):e20540. doi: 10.5812/hepatmon.20540. [PubMed: 25237372].

4. Javadi AA, Avijgan M, Hafizi M. Prevalence of HBV and HCV infections and associated risk factors in addict prisoners. Iran JPublic Health. 2006;35(4):336.

5. Aydin OA, Yemisen M, Karaosmanoglu HK, Sargin F, Gunduz A, Ceylan B, et al. Low Prevalence of Hepatitis CVirus Infection Among HIV-Positive Patients: Data From a Large-Scale Cohort Study in Istanbul, Turkey. Hepat Mon. 2014;14(8):e18128. doi: 10.5812/hepatmon.18128. [PubMed: 25337142]. 